\title{
JOHN LIEP
}

\section{LUFTBÅREN KULA DANSKE FELTORNITOLOGERS TILEGNELSE AF FUGLE}

...det er netop på grund af denne udveksling, fordi de hele tiden er ... genstand for et rivaliserende begær, fordi de er et middel til at vække misundelse og til at tildele social anseelse og berømmelse, at disse genstande opnår deres høje værdi.

Malinowski (1922:511)

Som altid anspores min interesse i et antropologisk problem af konkrete empiriske forhold. Jeg har i nogen tid grundet over, om min ganske omfattende erfaring i følge med folk, der ser på fugle, kunne omsættes i en faglig antropologisk analyse. Emnet befinder sig indenfor et langt mere omfattende felt, der kunne kaldes the anthropology of leisure og som det fremgår, angår det også udforskningen af konsumtion som kulturelt fænomen.

Inden for konsumtionsforskningen er der to hovedfortolkninger af forbruget. For nogle forskere er forbruget rettet mod andre (other directed). Forbrugeren tilegner sig ting og knytter dem til sin person for at skille sig ud fra andre og demonstrere sin status. Forbrugsvarer forstås her som statussymboler og forbrugeren som motiveret af konkurrence med andre forbrugere i et statushierarki. Denne tilgang går tilbage til Veblens The Theory of the Leisure Class (1975) og fortsætter i Bourdieus Distinction (1984). Ifølge den anden tilgang, som især inspireres af Colin Campbell (1987), retter forbruget sig først og fremmest mod forbrugerens selv (inner directed). Forbrugeren drives af et begær efter nydelse, der rettes mod ting og oplevelser, som forbrugeren drømmer om vil tilfredsstille begæret. Mere bredt ses forbrug som menneskers konstruktion af selv og identitet gennem tilegnelse af omverdenen (Miller 1987). De to tilgange udelukker ikke hinanden, og jeg bruger dem begge til at forstå det foreliggende fænomen: danske ornitologers tilegnelse af fugle.

Stående overfor det for antropologen fremmede: et fænomen i hans eget samfund, kan det være en genvej at tage udgangspunkt i det kendte: et fremmed samfund. Jeg begynder derfor på øen Rossel i Papua New Guinea.

\section{Fugle og identitet på Rossel Island}

Nogen tid efter min ankomst til Rossel Island var jeg på besøg i landsbyen Pum, hvis egnethed som sted for mit feltarbejde jeg ville undersøge. Jeg blev i denne forbindelse 
introduceret til egnens førende big man, Pönda. Under samtalen spurgte han mig om, „hvad min fugl var.“ Jeg vidste allerede, at de matrilineære klaner på Rossel (og iøvrigt i Massim-regionen) har fugletotemer. Da lærken i min barndom var Danmarks almindeligste fugl og kunne regnes for vor nationalfugl, svarede jeg, at det var en lille, brun fugl, der fløj højt op i luften og sang, hvorpå den dalede ned i kredse til jorden igen. Pönda svarede, at det var netop hans fugl temöli. Nu er braminerglenten, som det viste sig, at det drejede sig om, en noget større fugl, rødbrun med hvidt bryst, men den kredser rigtigt nok højt over landskabet.

Det er tænkeligt, at Pönda, der gennemgående, som Sahlins siger om big men, havde „blikket urokkeligt rettet mod egen fordel“ (Sahlins 1963, min oversættelse), så en fordel $i$ at etablere et vist identitetsfælleskab med en hvid og antagelig rig mand. Bestemmelsen af, hvilken fugl jeg ,havde,“ gav mig i hvert fald en placering i lokalsamfundet. Jeg hørte nu til Pöndas klan taa. En nabo i Pum, hvis far havde været taa, begyndte at kalde vores søn for „,bror“. Vi var ved at falde på plads i Rossels sociale kategorier. På samme måde fastlægger man klanen for tilflyttere fra andre øer i regionen.

Som sagt har hver af de femten klaner på Rossel en fugl som totem - foruden nogle planter eller træer, nogle fisk eller andre havdyr og en bestemt mytisk slange, en inkarnation af en guddom, der holder til på et helligsted på klanens område. Det drejer sig om det system af ,forbundne totemer“, der er karakteristisk for Massim-regionen (Seligman 1910:9). Øen er opdelt i klanterritorier, der som regel omfatter et højdedrag, et vandløb, en kyststrækning og en del af koralrevet. Hele det lokale univers - eller karakteristiske dele af det - er delt op mellem de sociale kategorier. I virkeligheden er det mere kompliceret, for klanerne er spredte, og de fleste er opdelt i lokaliserede subklaner, som territorierne er knyttet til. Kun de mindre, udelte klaner har kun én fugl. De større, segmenterede klaner har flere. For den største klan på øen fandt jeg f.eks., at to subklaner havde den grønne papegøje, tre den røde papegøje og én brillefuglen. ${ }^{1}$ Forskellige naturlige arter bruges altså til at markere sociale forskelle. Men processen kan også gå den modsatte vej. En klan kan yderligere spaltes og den sociale tanke etablerer forskelle i naturen, hvor der er behov for dem. Det viste sig f.eks., at man skelnede mellem tre forskellige røde papegøjer, der hver især var totem for en eller flere underklaner: en stor, der var prototypen, og desuden en mellemstor og en lille. Nogle subklaner fra forskellige klaner har en ,blandet afstamning“, der kan markeres ved, at de deler et totem - en fugl, plante eller fisk.

Fugletotemer på Rossel blev ikke betragtet med ærefrygt. Der var ikke forbud mod at dræbe eller spise dem eller nogen forestilling om nedstamning fra dem. De betegnede social samhørighed med klanmedlemmer, forskel fra folk fra andre klaner, og kunne også bruges til at udtrykke slægtskabsbånd på tværs af klaner. Rosseleserne tilegner sig altså fuglearter som kollektive gruppebesiddelser, der udtrykker identitetsfællesskab og -forskel konkret og kvalitativt. Som emblemer for identitet kan de forbindes med visse følelser. Da vi i 1980 tog afsked med min nære ven James, nævnte han med en vis bevægelse, at hans subklan, foruden den hvide kakadue havde endnu en fugl, ,en anden temöli, kaldet tile“. ${ }^{2}$ Man kunne altså sige, at vi havde fælles fugl. Når jeg så ,min fugl“ i Danmark, kunne jeg da tænke på ham. 


\section{Forholdet til fugle i Danmark}

Når vi nu flytter scenen til vores egen verden, står vi overfor langt større kompleksitet. En del af befolkningen er indifferent overfor fugle. Andre grupper har meget forskellige forhold til dem. Forholdet til fugle har desuden forandret sig historisk og er forbundet med videre områder af diskurs og praksis som det ændrede forhold til naturen og de grønne bevægelser. Man kan til en begyndelse skelne mellem en ,traditionel“ og en ,,alternativ" holdning.

Ifølge den traditionelle holdning er naturen til for menneskenes skyld, det er fremskridt at udvikle sin beherskelse af den, at gribe ind og regulere den til vores praktiske fordel. Det er fremskridt at regulere åer og afvande vådområder, så landbrugsarealer kan udvides. Det er nyttigt at skelne mellem ,jagtbart“ og ,skadevoldende“ vildt og bekæmpe det sidste for at bevare eller forøge jagten på det første. Oprettelsen af fasangårde i forrige århundrede førte således til en omfattende bekæmpelse af rovfugle, der først sluttede i 1960'erne (Gensbøl 1984:48-49). Indenfor den traditionelle holdning kan der godt opstå interessekonflikter. Landmænd vil f.eks. afvande områder, som jægere vil bevare som jagtterræner. Jagten som praksis er også kulturelt differentieret fra overklassens ritualiserede herregårdsjagter til den ,lille mands" strandjagt fra skydeprammen. I landområderne er der stadig en stor opslutning om den traditionelle holdning. Jægerens færden med bøsse og hund er dér endnu en agtet naturtilegnelse.

Den alternative holdning har udviklet sig med væksten af industrien, bylivet og middelklassen. Her er naturen blevet et modbillede til moderniteten, fremmedgørelsen og det materielle forbrug, man er omgivet af. Man gribes af bekymring over den moderne verdens fremtrængen og den svindende natur. Man frygter industrien og landbrugets forgiftning af miljøet. Man kæmper for fredning af ,traditionelle“ bygninger og landskaber eller for bevaring eller generobring af naturlige miljøer. I dette modsætningsfulde felt af modernitetsudvidelse og modernitetskritik finder ornitologien også sine bestemmelser.

\section{Ornitologiens udvikling}

Jeg tænker her ikke først og fremmest på det videnskabelige studium af fugle - omend indflydelsen herfra, som vi skal se, er betydelig - men på den folkelige praksis, amatørornitologien. Midt i forrige århundrede skilte en ornitolog sig kun ud fra sine jagtdrivende standsfæller ved en særlig interesse for fuglene. Niels Kjærbølling, der oprettede Københavns zoologiske have og skrev den første folkeligt udbredte bog om Danmarks Fugle, skriver således, at man ikke uden undtagelse bør tilintetgøre rovfuglene, da mange gør nytte ved at fortære ådsler og udrydde skadelige dyr. Men han fortsætter dog straksmed at beskrive, hvordan de kan skydes fra kragehytten lokket af en lænket ,bjergugle“, fanges i slaggarn, eller tages i fælder som rottesakse, svanehalse eller høgebure (1852:24). Art for art (bortset fra de små sangfugle) anfører han de bedste jagtmetoder. Om flagspætten oplyser han f.eks., at man kan efterligne dens hakken på træerne ved at slå med en nøgle på geværkolben. Den kommer da „strax nærmere, for at finde sin formentlige lige, og man kan da let skyde den“ (ibid.:62).

Disse råd, der byggede på personlige erfaringer, var ikke bare henvendt til jægere i almindelighed, men jo i særdeleshed til de særligt fugleinteresserede. Dengang var tileg- 
nelsen af fugle direkte og håndgribelig: enhver med stærk interesse for fugle oprettede en samling af udstoppede eksemplarer. Om de sjældnere fugle oplyser Kjærbølling, hvor i landet de er truffet, så at sige, og i hvis samlinger de er endt. ${ }^{3}$ På denne tid var det også almindeligt at anlægge store ægsamlinger, en interesse, der fortsatte langt op i dette århundrede, og af enkelte for nylig har været drevet illegalt, hvilket har forårsaget skandaler i Ornitologisk Forening. ${ }^{4}$ Mange ornitologer publicerede i Dansk Jagttidende indtil stiftelsen af Dansk Ornithologisk Forening i 1906 (Preuss 1981). Det gjaldt således A. H. Faber, der skrev om fugle på min barndomsegn omkring Horsens (Faber 1898). Af ham findes et fotografi, hvor han bærende jægerhat og bøsse betragter et kunstfærdigt opstillet udvalg af sin fuglesamling (Preuss ibid.).

Omend Dansk Ornitologisk Forening (DOF) fra sin stiftelse i 1906 som formål også havde at virke for beskyttelse af den danske fuglefauna, anføres i foreningens love indtil 1960 dog kun, at det skal ske ved afholdelse af møder og ekskursioner, udgivelse af et tidsskrift og oprettelse af et bibliotek. Bestyrelsen syntes i mange år ikke synderlig interesseret i beskyttelsesarbejdet, men lagde vægt på tidsskriftet og en videnskabelig linie (Frølich 1981). Efterhånden indtrådte dog en holdningsændring $i$,,den oplyste befolkningsklasse.“

Otto Helms, der var foreningens anden formand, skrev i 1920'erne det næste udbredte, populære værk om landets fugle (Helms 1927-32). Her sporer man endnu i beskrivelserne af de jagtbare arter, at der også tales ud fra jagterfaring, men Helms har dog tillæg om „Hvorledes man freder Fugle og holder dem til ved Boligen“ og om „Fredning af Strandfugle.“ Det er dog, forsikrer han, ikke hans tanke, at man ikke må gå på jagt, eller at fuglene skal have fuldstændig fred på menneskenes bekostning. ,,... som Samfundsforholdene er, maa Mennesket have de første Rettigheder, men disse er ikke uforenelige med en fornuftig Fuglefredning“" (Helms 1927:91).

Fra 1960'erne og 70'erne bliver foreningen markant mere aktiv og udadvendt. Efter krav fra feltornitologerne inddrages medlemmerne i store undersøgelser af fuglefaunaen, der nedsættes et fredningsudvalg og en fond, der opkøber og værner fuglelokaliteter. I takt med væksten i ,de grønne bevægelser“ bliver fredningskravene mere omfattende og radikale hos medlemmerne og modsætningen til jægerne mere udtalt. Foreningen gør sammen med Danmarks Naturfredningsforening fredningssynspunkter stadig stærkere politisk gældende. I forbindelse med udviklingen af hele miljøspørgsmålet som diskurs og problemfelt øges den offentlige monitorering af bl.a. fuglelivet så meget, at foreningen i 1986 kunne stifte et selvstændig konsulentselskab Ornis Consult, der bistår med naturregistrering og -overvågning (Fugle 7(1):2). Samtidig har foreningen, som det i en årrække er lykkedes at tiltrække en bred skare af medlemmer med diffuse naturinteresser, i de senere år i stigende omfang tilfredsstillet medlemmernes forbrugsbehov gennem DOF-salg, der udbyder et væld af varer fra fuglelitteratur, videoer og kikkerter til redekasser og t-shirts. Foreningens virksomhed afspejler således direkte modsætningen mellem hengivelsen til den ,vilde“ natur og tilfredsstillelsen af den voksende forbrugspraksis i samfundet.

\section{Fugleinteressens nuværende spredning}

Spekteret af folk, der på en eller anden måde omgås med vilde fugle, rummer en række afskygninger. Jeg har allerede omtalt jægerne, der i de senere år har oplevet en stigende 
folkelig afstandtagen, omend de som sagt endnu omfattes af velvilje i de endnu ,traditionelle" lag af befolkningen. Hvad „fuglevennerne“" angår, er den største og mest diffuse gruppe de mange borgere, der befinder sig i et i hovedsagen domestisk forhold til fuglene. Det er dem, der sætter ynglekasser op i haven, nyder fuglene ved foderbrættet og ved lejlighed besøger et fredet område og bestiger fugletårnet. Det er dem, der ser de folkelige naturprogrammer i TV og afgør gennem seerafstemninger, at nationalfuglen skal være knopsvanen, som de kender fra byparken. Ved foreningens ekskursioner, optræder de mest som ældre damer, der spørger om, hvad „,den smukke røde fugl er“ og får at vide, at det er en bogfinke. Blandt de mere erfarne omtales kategorien ironisk som ,foderbrætsfolket. "De har i nogle år udgjort en betydelig del af foreningens medlemmer, som den har tilgodeset ved særlige foderbrætstællinger og en styring af foreningsbladets profil i en mere almen, bredt fredningsorienteret retning med hyppige indslag om de mere kendte fuglearter.

Denne drejning har også kunnet dække behov hos en ,grøn“" gruppe, hvis naturinteresse har taget karakter af en politisk bevægelse, og som kæmper for vide beskyttelsesforanstaltninger i retning af omfattende fredninger, bekæmpelse af forurening, genoprettelse af engarealer og vådområder og yderligere jagtbegrænsninger. Som i det øvrige samfund kan en bred bevægelse udarte sig til en mere militant og ekstremistisk fraktion. En drastisk og medierettet manifestation af denne tendens var, da den lille aktionsgruppe Pugnax (brushane) demonstrerede i 1985 foran Fredningsstyrelsen i København, hvor de paraderede ligene af skarvunger, der var skudt ved dispensation på Ormø (Fugle 5(3):27). Ornitologernes fastholden af en konsekvent fredningslinie i forhold til skarven, der efter totalfredningen i 1980 steg fra et par tusind par til over 37.000 i 1994 (Bregnballe \& Gregersen 1995:125), bringer dem i modsætning til de traditionelle kredse i befolkningen, der anser den for at skade fiskernes næringsliv. Her anser man, ,jævne folks" livsform for truet af menneskefjendske naturelskere og et stadig omsiggribende formynderi fra København.

I, felten“ beskæftiger en del ornitologer sig med lokal overvågnings- og registreringsindsats af rastende eller ynglende fugle i bestemte områder, af særlig udvalgte artsgrupper eller af plejeforanstaltninger som opsætning af redekasser. Her er gerne tale om folk med et stærkt lokalt engagement, der våger over deres område, som de følger året rundt. Deres identitet er tæt knyttet til lokalområdet, og de reagerer ofte fjendtligt, når fremmede fra den næste gruppe-de mere mobile fuglekiggere, hvis tilbøjelighed er nydelsen af sjældne arter - trænger sig ind på „,deres“ lokalitet. Det er denne sidste kategori, jeg især vil beskæftige mig med, da den frembyder særligt interessante og paradoksale træk.

\section{På toppen af bakken ${ }^{5}$}

„Feltbisser“" er et udtryk, der bredt dækker de ornitologer, hvis væsentlige aktivitet er at se på fugle i marken. Feltbisser befinder sig så meget som muligt på udkig, men især hvor mængden og udvalget af fugle er størst muligt. Derfor strømmer de til de mange træklokaliteter, der i årenes løb er etableret som gode. Om foråret vil man således finde dem på nordøstvendte kystfremspring og om efteråret på de tilsvarende i sydvest. Hvert sted har sin faste kerne bestående af lokale ornitologer og folk fra nærliggende byer, der i sæsonen opsøger stedet. De rigtig store lokaliteter som Skagen eller Blåvand tiltrækker folk fra hele landet. 
Hellebæk i Nordøstsjælland, som jeg besøger mest, er en typisk træklokalitet. Den nyder endda den status at have et betydeligt træk både forår og efterår. Lokaliteten blev opdaget som træksted i 1974 af to ornitologer fra København, og i de følgende år etableredes dens betydning gennem et stigende antal observationsdage. En lokalitet skabes gennem et samspil af naturlige og menneskelige betingelser. Der skal naturligvis være træk af et vist omfang, men kulturelt konstrueres lokaliteten gennem registreringer og årsrapporter. Socialt etableres den gennem det ry for et interessant træk, den efterhånden erhverver sig. Hellebæk har i en årrække været anerkendt som en af de bedste forårstræksteder i Nordsjælland.

På en god dag i april vil man her finde fra 10-15 til i weekenden op til et halvt hundrede ornitologer samlet på en bakke i et overdrevsområde. Den faste kerne består af under en halv snes mand, der indtager bakketoppen. Det er folk, der har kendt hinanden igennem mange år, og som knyttes sammen af en stor fond af fælles oplevelser og erfaringer. De suppleres af en kategori af mere mobile, men lige så kendte og erfarne besøgende og af folk med fast arbejde, der kun kommer i weekenden. I periferien befinder sig mindre fortrolige eller erfarne fuglekiggere og søndagsgæster, der kun viser sig enkelte dage i sæsonen.

Den dagligt og årligt gentagne interaktionsproces på lokaliteten etablerer et mønster, der bygger på to faktorer: mangeårigt oparbejdet fælles fortrolighed og praktisk dygtighed $\mathrm{i}$ identifikation af fugle. Veteraner med årelang erfaring har opøvet et mesterskab $\mathrm{i}$ identifikation, der støtter sig på intimt kendskab til fuglenes dragtdetaljer, flugtadfærd og kald, selv under vanskelige iagttagelsesforhold, og som kan mobiliseres som habitus i en hurtig identifikationsproces. De frembyder en evne til koncentration, der sætter dem i stand til at opdage trækkende fugle på maksimal afstand og løbende holde sig a jour med trækket flere steder på himmelen samtidig. Denne fordybelse ledsages forståeligt nok af en vis social utilnærmelighed.

Inkarnerede ornitologer har endvidere tillagt sig en disciplin, der består i løbende registrering af art og antal af trækkende fugle over tidsperioder. Det foregår ved notering i de sorte, kinesiske notesbøger med rød ryg, der er uofficiel standard. Denne notering, der er optaget fra naturvidenskabelig praksis, sætter dem - i forbindelse med oparbejdet tillid til deres iagttagelsers pålidelighed - i stand til når som helst at „,overtage vagten“ og tage ansvaret for registreringen af lokalitetens træk. Forskellige iagttageres observationstimer bliver efterhånden konfereret og føjet sammen til et autoriseret resultat, der samlet indgår i lokalitetsrapporten. Over hele landet strømmer et stort antal ornitologers observationer sammen i årlige amtsrapporter og landsrapporter. Dette omfangsrige kvantitative materiale danner baggrund for mere videnskabelige afhandlinger, men giver også foreningen en dokumentation i hænde, der har overbevisende politisk vægt.

Samtidig bliver denne kvantificeringsdisciplin en karakteristisk del af mange ornitologers habitus, således at deres adfærd i naturen udmønter sig i optællinger. Den naive besøgende, der nærmer sig denne type ornitolog i felten og tror, at her er en meningsfælle, med hvem man kan indlede en hyggesnak, risikerer at blive vist af med et ,Jeg tæller!“ sagt ud af mundvigen. Sådanne fuglekiggere oparbejder rækker af notesbøger, der hovedsagelig består af registreringer, som kun sjældent finder videnskabelig brug, men bliver et særegent index til svundne oplevelser.

Den sociale konfiguration på bakken konstitueres af et typisk dansk samspil af lighed og hierarkisering. ${ }^{6}$ Her blandes læger og ingeniører med arbejdsløse uden stands anseelse, og indkomstforskelle underkommunikeres ligeledes. Det spiller f.eks. ikke nogen 
væsentlig rolle, hvad ens kikkert og teleskopudstyr har kostet, ligesom kostbar feltbeklædning ikke giver status. Nogle af de gamle feltbisser holder stædigt fast ved deres slidte og mindre højtydende teleskoper. ${ }^{7}$ Til gengæld kan man kan nu og da se gæster, der har erhvervet deres fugleinteresse i en moden alder og efter opnåelsen af et behageligt indkomstniveau. De kan kendes på smart friluftsbeklædning og dyre kikkerter, men afslører sig snart ved at måtte ty til fuglebogen (jf. Sonsino 1989:10 om ,dudes“).

Hierarkisering vedligeholdes gennem et socialt spil, der upåfaldende bekræfter og tildeler værdier om dygtighed, autoritet og omdømme. En sig fjernt nærmende fugl vil blive opdaget af et af kernemedlemmerne, som gennem ,prikidentifikation“ anslår dens art. Andre centrale gruppemedlemmer vil som regel gennem nogle få vink kunne finde fuglen. Efterhånden som denne nærmer sig, udveksler de erfarne bemærkninger om dens køn og alder, og en sikker identifikation kan etableres, selvom fuglen passerer stedet på stor afstand. Imens afsøger de mere uerfarne observatører endnu under stigende frustration horisonten. Nogle arter som falke eller småfugle, der bevæger sig hurtigt, dukker pludselig op. De kræver et lynsnart identifikationsberedskab og frembyder større risiko for fejlidentifikation. Selvom etableret erfaring udgør en anerkendt kulturel kapital og et grundlag for en høj og stabil status, bliver den demonstreret og udfordret med mellemrum. I det gensidige joking relationship kan en fejlidentifikation fra en af de gamle rotter blive fejret med spottende begejstring, mens en tilsvarende fra en mere uerfaren mødes med kølig affærdigelse eller sigende tavshed.

På lokaliteter, hvor feltbisser mødes i praksis, findes altså et socialt felt med veletablerede værdier og uformelle regler for, hvordan de konkurreres om og erhverves (jf. Bourdieu 1991). Gennem årene kan et personligt omdømme forøges og udvides til omfattende ry og respekt i landsdækkende fuglekredse. Men det vil være utilstrækkeligt at indskrænke en analyse af de inkarnerede ornitologers selvkonstruktion til denne sociale proces. Her indgår også en kulturelt konstrueret, men personligt indlejret, motivation, der angår mere dybtliggende begærsbesætninger.

Nok tilfredsstilles ornitologerne på bakken af en god trækdag med variation og mange fugle. Men de anspores dog yderligere af forhåbningen om det særlige: at en sjældenhed skal vise sig. Det er derfor, at udråbet „Storfalk!“ eller „Ørn!“ udløser mærkbar spænding og opstemthed. Omend fugleriget omfattes af et vist udefineret hierarki, hvor rovfugle for de fleste står øverst, følger værdisætningen af fugle først og fremmest sjældenhed ${ }^{8}$ Det er derfor, at ornitologer, der ellers er knyttet til deres faste træksted, søger til en stjernelokalitet som Skagen, der er kendt for særlig artsrigdom og hyppig forekomst af rariteter. Felterfaring og viden kan her uddybes, men det spiller også en rolle, at der er større chance for at „få“ et ,hit“.

\section{Hitjægere og twitchere ${ }^{9}$}

Den 14. november 1983 opdagedes en ismåge i Hanstholm Havn. Det var kun femte gang, den optrådte i Danmark, og nyheden bredte sig hurtigt. ,[M]ange feltbisser smed, hvad de havde i hænderne, og tog til Hanstholm“ (Skriver 1984). Fire københavnere forlod arbejdet og nåede efter bil- og færgerejse frem til Hanstholm, hvor de opholdt sig i to timer. ,Så havde de set ismågen og trillede derpå østover rolige i sjælen“ (ibid.). Andre benyttede flyruten København-Thisted. Selv fra Skåne og Göteborg ankom fuglekiggere. Torsdag 
den 25. november var fuglen fløjet, men endnu herefter strømmede ornitologer til, blandt andet en ny københavnsk delegation, der havde glædet sig til at møde frem ved DOF's repræsentantskabsmøde dagen efter med friske nyheder. Da de sent lørdag nat vendte hjem til København, ,,var stemningen slet ikke som hos den første delegation ...“ (ibid.).

Påstyret om ismågen gav endnu kun anledning til hovedrysten hos mange feltbisser, men kun godt to måneder senere udløste opdagelsen af en rosenmåge i Thorsminde Havn (kun andet fund) en massiv valfart. ,Allerede morgenen [efter fundet] sås - til de lokale fiskeres store forbløffelse - de første biler med overnattende ornitologer ... og den påfølgende weekend oplevede det lille jyske fiskerleje det hidtil største sammenrend af ornitologer, man har set noget sted i landet“ (Enevoldsen et al. 1984). Fænomenet „twitching“, det vil sige, at såkaldte ,hitjægere“ begiver sig på langfart for at se en sjældenhed, var født. ${ }^{10}$

Disse første beretninger meddeler om det begær efter at se en eftertragtet raritet, der får mænd til at forlade deres arbejde og haste mod fjerne egne af landet. De vidner også om den tilfredstillelse, der følger efter begærsopfyldelsen eller det mismod, der indtræffer, hvis den skuffes. Endelig antyder de en vis skadefryd fra de heldige overfor de mindre heldige. I det følgende skal jeg antyde nogle dimensioner af denne udvikling indenfor fuglekiggeriet, der har taget et stigende omfang i de senere år.

De psykologiske mekanismer bag jagten på sjældenheder eller ,hits“, som de hedder i den internationaliserede jargon, er utivlsomt meget almene og ligger under alverdens samlermani, og den dertil knyttede konkurrence. Det er en motivation, der er gjort almen i det moderne vareforbrug. Der er tale om en konstitution af selvet, hvor akkumulationen bliver et mål i sig selv. Begæret rettes mod erhvervelsen af stadig flere enheder af det særlige kulturelt konstruerede og værdiladede objekt, som værdsættes i det sociale felt, man er tilsluttet. Her drejer det sig om fugle. I dette særlige spil strækker felterne sig over hele landet. Chancerne for brikkernes tilsynekomst kan til en vis grad forudsiges, men afhænger i sidste ende af tilfældet. Når heldet indtræffer, kan alle de spillere, som er til stede eller når frem i tide - hvis de besidder den fornødne felterfaring - hæve gevinsten, mens de, der overser en hurtigtrækker, eller ikke når frem, har tabt. Hvor tidligere tiders ornitologer som omtalt tilegnede sig objekterne håndgribeligt og besad dem som udstoppede eksemplarer, er det nu tilstrækkeligt, at man har set en sjælden fugl - og kan dokumentere det. ${ }^{11}$

I Danmark (som i andre af de lande ,,vi sammenligner os med“) findes et Sjaldenhedsudvalg nedsat of Ornitologisk Forening, der bedømmer og autoriserer indsendt dokumentation for iagttagne sjældenheder. Kun godkendte iagttagelser kan offentliggøres i foreningens publikationer og for nye arters vedkommende optages på den danske artsliste. I særligt vanskelige tilfælde kan godkendelse bero på medsendte fotografier eller lydoptagelser, men i reglen er det nok, at beskrivelsen er detaljeret og overbevisende. Kredsen af de, som kan få en iagttagelse officielt godkendt, begrænses derfor til dem, der er i stand til at formulere og eksplicitere deres iagttagelser på et tilstrækkeligt niveau. Det forekommer også mere overbevisende, at beretningen indsendes af flere iagttagere med anerkendt erfaring. Medlemmer af SU, som det omtales, har til mig udtalt, at sager med utilstrækkelig dokumentation ofte forkastes, men at forsøg på svindel er så godt som uhørte. Der hersker altså en velindarbejdet etik, som kræver, at man ikke snyder. Modsætninger mellem SU og feltornitologer opstår dog fra tid til anden, hvis der breder sig en opfattelse af, at udvalget anlægger en for restriktiv linie. For selv om man ikke opfinder 
fugle, man ikke har set, er sjældenhedstrangen så stærk, at ønsketænkning under krævende iagttagelsesforhold er en faktor, der kan påvirke identifikationsprocessen. Når én indsendt iagttagelse af et individ er godkendt, er det tilstrækkeligt til, at andre, der har set den samme fugl, med god samvittighed kan føje den til deres personlige „DK-liste.“

Det gælder altså om at forøge antallet på sin liste over DK-arter. ${ }^{12}$ En fugl set uden for landets grænser ,gælder“ ikke på samme måde. Den moderne udvikling af transport- og kommunikationsområdet er grundlaget for denne højst specialiserede naturtilegnelse. Bilismens almindelige udbredelse har tilladt et højt antal mennesker at bevæge sig hurtigt til fjernere steder udenfor det offentlige transportnetværk, og flyruternes udbygning gør det muligt inden for den samme dag at befinde sig i den anden ende af landet. Allerede i mange år har et vidt omspændende netværk af telefoniske kontakter, struktureret i uformelle sociale centre og periferier, forbundet ornitologer og spredt nyheder om opdukkede sjældenheder til en større eller snævrere kreds. Kendskabet til forekomsten af sjældenheder er dog siden 1991 blevet demokratiseret, efter at en efterhånden landsdækkende dagligt opdateret telefonservicelinie oprettet af DOF har meddelt nye iagttagelser. Da mange fugle imidlertid kun opholder sig i kort tid på en lokalitet, er der stadig behov for hurtig kommunikation, og ivrige hitjægere drager her nytte af mobiltelefonen, der nu ofte ses og høres på trækstederne. Ved hjælp af den kan man også i felten underrettes om nyopdagede sjældenheder, og på større træklokaliteter som Skagen kan man holde kontakt mellem forskellige observationspunkter.

I Finland og Sverige er mere avanceret højteknologisk kommunikationsudstyr nu i brug blandt ,hårdskådare.“ Det drejer sig om personsøgeudstyr med op til 400 tegn, hvor detaljerede oplysninger om rariteter løbende indkodes (Elmberg 1994). Dér og i England formidles denne service af specialforeninger med høje medlemskontingenter og serviceafgifter, såvel som af kommercielle servicekanaler. Selvom DOF foreløbig har inddæmmet behovet for aktuel raritetsinformation, er det sandsynligt, at denne udvikling snart vil brede sig til Danmark.

Der er dog tegn på, at dette vil medføre en yderlige opspaltning af det ornitologiske felt. Mange feltbisser reagerer mod denne højteknologiske og økonomisk stadigt mere krævende tilegnelsesform, hvor en oplevelsestrang, der i udgangspunktet vendte sig bort fra moderniteten, bliver udsat for kapitalisering og varegørelse af livsoplevelserne.

Hitjagten har allerede givet anledning til ophedede debatter i foreningsbladet, hvor hitjægere anklages for ulovlig indtrængen på privat eller fredet område og for forstyrrelse af naturfreden. Omvendt har feltornitologer kritiseret foreningens popularisering som en ,,alternativ naturfredningsforening “ og påpeget et stigende behov for en ny feltornitologisk forening. ${ }^{13}$ DOF har i 1995 søgt at løse disse modsætninger ved at opsplitte sit populære foreningsblad Fugle i to.

\section{Hitjægerens personkonstruktion}

I Sverige findes en Klub 300 af ornitologer, der har set 300 arter. I Danmark eksisterer en Klub 300 kun som begreb, noget man kan være ,med i“ eller stræbe efter at opnå, og som af mange anses for det magiske vandskel i deres ornitologiske selvfuldkommengørelse. Men for dem, der allerede har nået de 300 arter, standser begæret ikke, men fortsætter mod nye grænser. Som Campbell skriver ,... drømmen vil blive overført til en ny gen- 
stand for begær, således at denne illusion om tilfredsstillelse kan blive oplevet påny“ (1987:86). En dansk ornitolog beskriver processen næsten tilsvarende: ,,... tilfredsstillelsen og drømmen går side om side, men hver for sig, og begejstringen over en god dag, afløstes altid hurtigt af drømmen om en ny god dag“"(Bertel 1994:85).
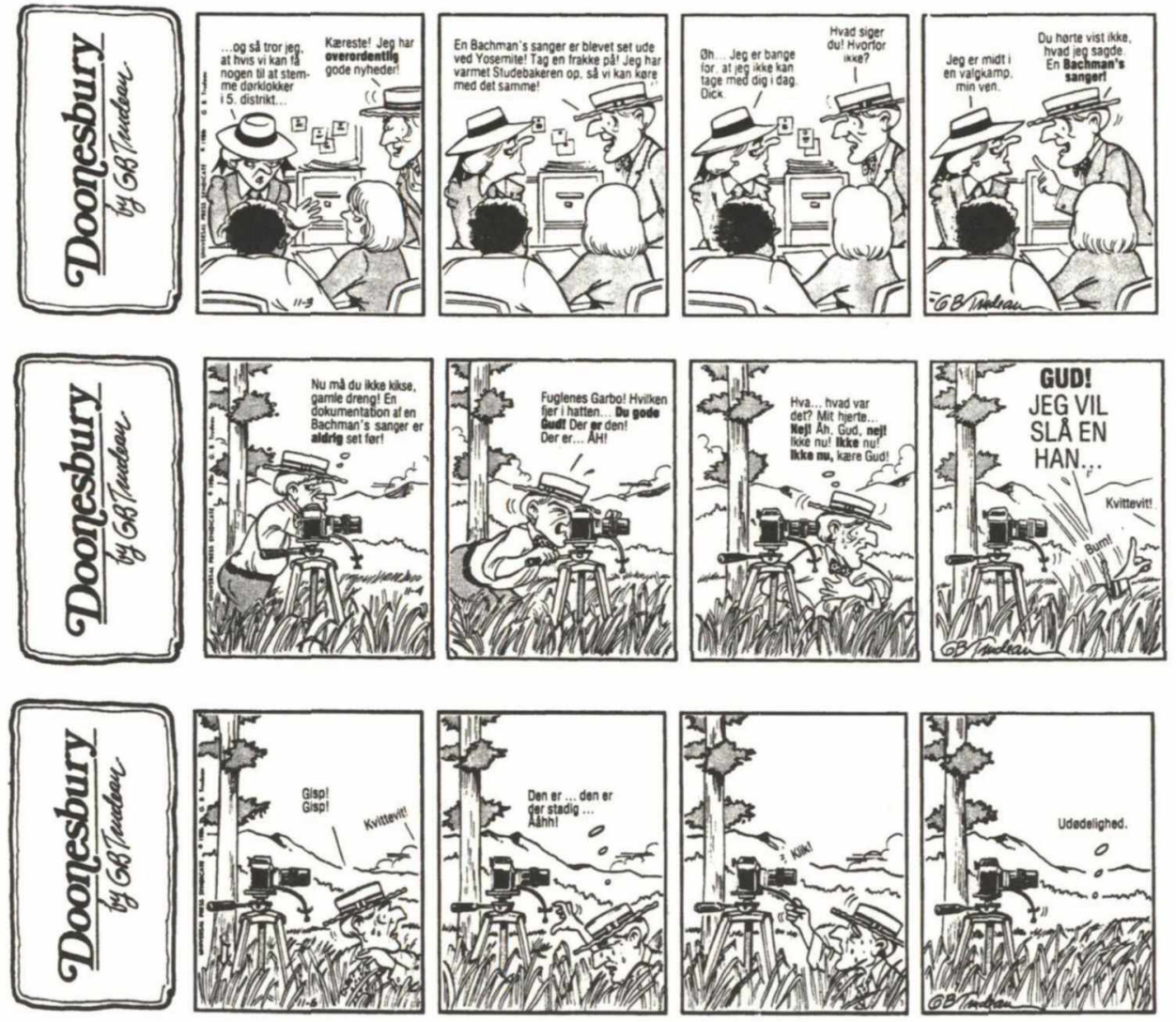

I foråret 1995 så jeg på Skagen Danmarks selverklærede mest fanatiske hitjæger, en mand der går under øgenavnet „Munken“ (efter hans mellemnavn Munck), prydet med en lærredshat, hvortil han havde fæstnet en badge, der bar påskriften „Klub 350 - Munken“. På grund af hans særposition som ekstrem idealtype, der både betragtes med hovedrysten, men også med nogen misundelse, er Munken blevet en sagnskikkelse, og der findes en række myter om hans triumfer og nederlag.

Munken er murermester og kører en del omkring i forbindelse med sit erhverv. Hans virksomhed sætter visse grænser for den tid, han kan afse til fuglestudier, men giver ham til gengæld et økonomisk grundlag for hyppige rejser. Han har mulighed for at afbryde arbejdet og foretage hurtige afstikkere, og hans kunder kan kontakte ham overalt uden at vide, at han ikke befinder sig på sit kontor. Han er en sværtbygget mand med et rundt hoved og et ekstrovært og lattermildt gemyt, hvad der adskiller ham fra flertallet af ornitologer. Da en polarlomvie i 1989 (som det første levende eksemplar) blev fundet i Hundested Havn ringede de smålige indviede med vilje først til Munken efter vinternattens 
frembrud. Han lod sig dog ikke holde udenfor, men styrede straks mod havnen. Her kørte han helt frem på kajen, hvor det lykkedes ham at fange fuglen ude i havnebassinet i fjernlyset fra billygterne. Næste dag havde lomvien fortrukket (Personlig rygtemodtagelse, se også Olsen 1992).

Til gengæld er Munkens kvaler med Klippesvalen legendariske. I 1990 blev en klippesvale for anden gang i Danmark opdaget ved Hammeren. Munken fløj til Bornholm, men forsinkedes af tåge og måtte tage en taxa fra Rønne. Da han ankom, var fuglen sidst blevet set fem minutter tidligere. Dagen efter blev den imidlertid genfundet ved Svaneke. Samme nat sejlede Munken i selskab med tre andre hitjægere til øen og kørte straks til Svaneke. Da fuglen efter en time ikke havde vist sig, gik han og to af de andre til bageren for at købe wienerbrød og var borte i ti minutter. Imens ,havde“ den sidste mand klippesvalen i nogle lyksalige øjeblikke. Munken udtalte senere, at „... det var der jeg fik mit knæk..." (Rodahl \& Speierman 1993).

Faktisk drejer de fleste myter om Munken sig om hans ,misser“. Da han er ubestridt indehaver af artsrekorden, har de den moralske pointe, at selv sejrherrer lider frygtelige nederlag. De bringer ham tilbage i naturlig størrelse og i situationer, som alle hitjægere kender og frygter. Omgangsformen mellem feltbisser kan som i politiet være „rå men hjertelig“. Man forenes i samstemmig fryd ved den fælles oplevelse af en sjælden fugl, men dem, der kommer for sent, bliver underrettet med et smil i mundvigen og siden spottende mindet om deres uheld. Men historierne antyder også de følelsesmæssige ekstremer, som jagten på ornitologisk tilfredsstillelse fremkalder. Således beretter Munken om den rastløshed og forventning, der fremkaldes af meddelelsen om en amerikansk pibeand i Vejlerne:

Den spænding, der er, når man kører hjemmefra om aftenen ... og når frem om morgenen og skal se, om den er der, om man kan finde den. Den spænding holder jeg meget af ... Du kan jo se det med ornitologer generelt, de er jo totalt sindssyge, indtil de har set det, ikk', men så falder de til ro. (Rodahl \& Speiermann 1993).

Man ser her, hvordan et specifikt socialt og kulturelt fællesskab kan tilskrive objekter, der bogstaveligt talt er uhåndgribelige, den højeste værdi og gøre dem til genstand for et ubetvingeligt begær. Det er, som Susan Steward i en anden sammenhæng skriver, ,,...en voyeurisme, der på én og samme tid er ophøjet og distanceret“" (1984:134). ${ }^{14}$

Ornitologernes netværk indspinder naturlige objekter i et net af betydningsrelationer, der gennem gentagen interaktion, konkurrence og fælles fejring bekræfter deres høje værdi og eftertragtelsesværdighed. Den næsten tvangsmæssige akkumulation af arter repræsenterer en konstruktion af selvet og en forfinet form for konsumtion: „Det afg $\emptyset$ rende led i den serie, som en samling udgør, er 'selvet', artikulationen af samlerens egen 'identitet' ... Samlingen ... er den mest abstrakte form for forbrug” (ibid.:162, 164). ${ }^{15}$

\section{Konklusion}

Det var nu let at etablere en total kontrast mellem to former for konstruktion af selv og identitet: den kvantitative, individuelle og selvcentrerede tilegnelse af fugle hos en kategori af danske ornitologer og den kvalitative og kollektive tilegnelse i Melanesien, som jeg præsenterede først i dette essay. Men derved ville man forbise, at en objektfikseret, 
individuel kappestrid om ejendomsløs besiddelse af lige så kulturelt konstruerede objekter også finder sted i Sydhavet. Her drejer det sig om de smykker forarbejdet af tilslebne havskaller, der udveksles i kula-ringen (Malinowski 1922). Mænd begiver sig her ud på lange og farefulde søekspeditioner for at erhverve skaller, som de kun beholder for en tid for derefter at give dem videre til deres partnere. Enhver kula-deltager stræber efter fremgang i kulaen, at lade flere og mere eftertragtede kula-skaller gå gennem sine hænder for engang måske at nå det mål, at hans navn knyttes til en af de mest berømte kula-genstande og ,går ringen rundt“" (Weiner 1988:143). Men dermed er konsumtionsbegæret ikke opfyldt: "Vi vil smage på alle de berømte mwari og vaigua [armringe og halskæder]" (Campbell 1983:217). Damon beretter, at en mand under kula-forhandlinger kan true med selvmord, fordi „,...hans tørst efter en kula-genstand er større end hans livstørst“ (1993:251, n.15). En anden mand ,blev vanvittig“ på grund af en vis berømt kula-genstand (ibid.:252, n.21).

Både i Melanesien og hos os forekommer altså en selvkonstruktion gennem tilegnelse af fetisherede objekter i et socialt felt, hvor et fælles kulturelt grundlag for ansættelse og opnåelse af værdi tildeler deltagerne selvværd og berømmelse. Den væsentlige forskel er, at kulaen er den centrale kulturelle institution for konkurrence om omdømme på øerne i kula-ringen. I det moderne, fragmenterede vestlige samfund etableres et stigende antal felter med alternative grundlag for, hvad der er værd at stræbe efter.

Wilden har kritiseret Malinowski for at tilskrive kula-deltagerne et ,dybtliggende besiddelsesbegær," selv om han selv understreger, at kula-genstande ikke kan besiddes (1980:257). Senere konsumtionsforskning har udnyttet en skelnen mellem ejendomsret og besiddelse. Man kan f.eks. godt eje en upersonlig vare uden at føle, at ,den rigtig tilhører én“ (McCracken 1990:85). Kula-udvekslingen i Melanesien og den ,luftbårne kula“ $i$ Danmark viser til gengæld, at man lige så vel kan besidde - dvs. tilegne sig og inkorporere i selvet - noget man ikke kan eje. Malinowskis fortolkning af ejendomsløs besiddelse i Massim passer lige så slående på danske ornitologers luftbårne kula:

... det er ikke normal besiddelse, men en særlig type, hvor en mand for en kort tid ejer ... enkelte eksemplarer ... Skønt ejendomsretten i sin varighed er ufuldkommen, forøges den til gengæld i forhold til det antal, der successivt besiddes, og kan kaldes for kumulativ besiddelse (1922:510).

\section{Noter}

Dette essay blev skrevet til en workshop arrangeret af Institut for Antropologi, Københavns Universitet i januar 1996. Det er baseret på en slags feltarbejde iblandt fugle og folk i Danmark gennem godt ti år. Det kan kaldes feltarbejde, fordi folk, der ser på fugle i marken, kalder sig feltornitologer. Der har i hvert fald været tale om deltagerobservation i sin højeste form: jeg har observeret blandt folk, der selv observerede. Jeg har ikke foretaget formelle interviews, men benytter mig af enkelte publicerede, foretaget af andre. Jeg takker Stig Toft Madsen for mange fælles observationer og diskussioner gennem årene. For kommentarer til manuskriptet takker jeg ham og ornitologerne Ole Geertz-Hansen, Klaus Malling Olsen og Steen Søgård. Tekstforfatter Søren Lampe og korrespondent Susanne Purdy har hjulpet mig med oversættelsen af citaterne.

1. For at det skal fremgå, at jeg ved, hvad jeg taler om, anføres her de i afsnittet forekommende identifikationer (Rossel navn, engelsk navn, latinsk betegnelse). Braminerglente: temöli, Brahminy Kite, Halliastur indus. Grøn papegøje: tëna, Red-cheeked Parrot, Geoffroyus geoffroyi. Rød papegøje: mdye, Eastern 
black-capped Lory, Lorius hypoinochrous. Brillefugl: tää, Louisiades White-eye, Zosterops griseotinctus (Beehler, Pratt \& Zimmerman 1986).

2. Tile er faktisk braminerglentens ungfugl.

3. Om vandstæren skriver han således: „Hr. Greve, Ritmester G. Raben skød den ved Aastrup pr. Roeskilde ... Faber ... har skudt den ved Odense. Hr. Baron v. Brockdorff skød den ved Thyrsbæk ved Veile. Hr. Hofjægermester Teilmann i Decbr. 1822 ved Esrum Sø. Jeg har den fra Grenaa, Viborg, Apenrade, Veile, samt fra flere egne, og Hr. Apotheker Steenberg fra Helsingøer=Egnen“ (1852: 136). Af bogens øvrige sammenhæn fremgår det, at ,har" betyder ,i sin samling“".

4. I et interview udtales, at ægsamling endnu først i 1960 'erne ,red foreningen som en mare ... [d]en gamle generation havde startet deres interesse for fugle gennem ægsamling, som halvvejs var accepteret, da det kunne dækkes ind under en ... videnskabelig betydning. Men det var ren samlermani og man vidste godt, at det gik ud over de mest truede arter i landet, så man så på det med stor alvor" (Speiermann \& Søgård 1995:5). Endnu i 1983 afsløredes store illegale ægsamlinger hos en landsretssagfører og en marketingsdirektør, der var estimerede medlemmer af henholdsvis Dansk Ornitologisk Forening og Danmarks Naturfredningsforening (Geckler 1984).

5. Til dette afsnit har jeg modtaget inspiration fra Stig Toft Madsen (n.d.), der også har bistået med referencer.

6. Jeg er her inspireret af et konferensspeciale fra Institut for Antropologi (Anderson 1995).

7. Dette lidt puritanske anstrøg, der også afspejles i de omtalte sorte notesbøger, kendetegner den dominerende midaldrende generation, hvis identitet var præget af antimaterialismen under ungdomsoprøret (Klaus Malling Olsen, personlig meddelelse).

8. At rovfuglene synes at stå øverst i fuglenes kongerige er formentlig en forestilling med kulturelle rødder langt tilbage. Som predatorer øverst i fødekæden har rovfuglene været emblemer for konge- og adelsmagt - symboler på herredømme. Ørne optræder typisk i rigsvåben, og falkejagt var en riddersport forbeholdt adelen. Denne symbolske sociale position afspejledes indtil for nylig i fuglelitteraturen. Således skriver Thorvald Kjær endnu i 1946 om ,ædelfalkene“, at de har „Rejsning og Herskerblik, som kun den har, der føler sig bevidst om sin absolutte Overlegenhed“ (1946:55). Omend „den store udryddelse“ af rovfugle havde udgangspunkt $\mathrm{i}$ herregårdenes fasanhold, kan man antyde, at den store folkelige opslutning til billedet af rovfuglene som skadedyr kan have været næret af en metaforisk modvilje mod disse tidligere feudale symboler fra en frigjort bondestand.

9. Forfatteren til Bluff your way at birdwatching giver følgende oplysende kommentar om twitchere:

„Et trin over fuglekiggeren står twitcheren. Der er ingen, der er helt sikker på oprindelsen til navnet, men der er enighed om, at de [twitchere] enten spjætter [twitch] af ophidselse, når de hører om en sjældenhed, eller at de rykker [twitch] ud til andre dele af landet på mindste foranledning. I gamle dage var det ret svært at være twitcher. For det første hørte man aldrig om, hvad der var på færde, hvis man ikke lige var tilsluttet den udvalgte jungletelegraf, og for det andet gjaldt det om at beholde sit job. Nu, da der er så mange arbejdsløse, er det blevet meget lettere at twitche, fordi det nemt kan passes ind omkring de dage, hvor man stempler" (Sonsino 1989:9).

En alternativ oprindelseshistorie er, at nogle artsjægere på motorcykel i barskt vejr rystede af kulde, da de nåede frem til sjældenheden (Tony Clarke, personlig meddelelse via Klaus Malling Olsen).

10. Det drejer sig om twitching som landsdækkende disciplin. Allerede tilbage fra 60'erne havde enkelte sjældenheder forårsaget et mere lokalt sammenrend i Københavnssområdet (Klaus Malling Olsen, personlig kommentar).

11. Nogle vil her have anledning til at anføre Foucault og betragtninger om „the gaze“ eller synets særlige position under moderniteten. Da denne observation er gjort så ofte, vil jeg undlade at gentage den.

12. DK-listen over fugle set indenfor det nationale territorium er hitjægerens hovedmålestok for ornitologisk fuldbyrdelse. Men da den af naturlige grunde må være udsat for en faldende tilvækstrate, som årene går, kan akkumulationstrangen og rekordefterstræbelsen tilfredsstilles ved oprettelsen af en række andre lister. Man kan føre lister over arter, man har set $\mathrm{i}$ andre lande. Livslisten rummer alle de arter, man overhovedet har set. Mange har en årsliste over arter observeret i det pågældende år. Det medfører en livlig trafik nytårsdag, hvor ornitologer søger ud for at „tage hul på årslisten“ og selv helt almindelige arter for en dag kommer til værdighed igen. Andre fører en liste over matrikelarter, som de har set fra deres have. I de senere år har en selvbestaltet kreds af ornitologer afholdt et årligt Birdrace, hvor det gælder om at se et maximalt antal arter på 24 timer. Selv har jeg oprettet en liste over „missere“, hvor fugle, jeg ikke fik set, kan gøres til genstand for en vis fraværende tilegnelse. 
13. Samlet henvisning til denne debat: Meddelelser fra DOF (4):1987:1-2, DOF-nyt (2):i, (3):i-iii, (4):iv,1990, (4):viii-xi, 1993, (2):xi, 1994. Alle i Fugle.

14. Her må jeg dog straks korrigere mig selv. Fugle bliver faktisk grebet $\mathrm{i}$ hånden. Det sker ved ringmærkning, der af særligt autoriserede udføres i Zoologisk Museums regi. Det er dog en offentlig hemmelighed, at de unge ornitologer, der uden vederlag i månedsvis arbejder som ringmærkere, holdes oppe af håbet om, at en sjældenhed skal vise sig i nettet: ,[M] an går som regel og venter på at fange 'noget', det er det, man går og drømmer om på netruterne“" (Rodahl \& Speiermann 1993:8)). Derfor kan dem, der har ringmærket, tale om, at de har en fugl som "røreart ${ }^{\prime}$.

15. Hitjægerens mentalitet og adfærd er blevet fremragende kommenteret i den afbillede episode fra tegneserien Doonesbury. Her illustreres, hvordan efterretningen om en opdukket sjælden art får alle andre hensyn til at vige, fuglens stjernestatus sammenlignes med Greta Garbos og synet af den afstedkommer fatalt sindsoprør, men fører alligevel til den ultimative fuldkommengørelse af selvet: udødelighed.

\section{Litteratur}

Anderson, Sally

1995 Chronic Proximity and the Management of Difference: a Study of the Danish School

Practice of Klasse. Upubliceret Magisterkonferensspeciale, København: Institut for

Antropologi.

Beehler, Bruce M., Thane K. Pratt \& Dale A. Zimmerman

1986 Birds of New Guinea. Princeton: Princeton University Press.

Bertel, Bjarne

$1994 \quad$ Fugle over Skagen. Jyllinge: European Faunistcal Press.

Bourdieu, Pierre

1984 Distinction: A Social Critique of the Judgment of Taste. London: Routledge \& Kegan Paul.

1991 Language and Symbolic Power. Cambridge: Polity Press.

Bregnballe, Thomas \& Jens Gregersen

$1995 \quad$ Udviklingen af Ynglebestanden af Skarv Phalacrocorax carbo sinensis i Danmark 1938-

1994. Dansk Ornitologisk Forenings Tidsskrift 89(3):119-134.

Campbell, Colin

1987 The Romantic Ethic and the Spirit of Modern Consumerism. Oxford: Basil Blackwell.

Campbell, Shirley

1983 Kula in Vakuta: the Mechanics of Keda. I: Jerry W. Leach \& Edmund Leach (eds.): The

Kula: New Perspectives on Massim Exchange. Cambridge: Cambridge University Press.

Damon, Frederick H.

1993 Representation and Experience in Kula and Western Exchange Spheres (or, Billy). Research in Economic Anthropology 14:235-54.

Donelly, Peter

1994 Take My Word For It: Trust in the Context of Birding and Mountaineering. Qualitative Sociology 17(3):215-242.

Elmberg, Johan

1994 Lämna De Gula Gummistövlarna Hemma! Vor Fågelvärld (5):1719.

Enevoldsen, Erik et al.

1984 Rosenmåge i Thorsminde. Fugle 4(2):25.

Faber, Axel Hugo

1898 Optegnelser om Vejle- og Horsensegnens Fuglefauna i Aarene 1875-1897.

Gensbøl, Benny

1984 Rovfuglene i Europa, Nordafrika og Mellemøsten. København: G.E.C. Gad. 
Helms, Otto

1927-32 Danske Fugle I-III. København: G.E.C. Gad.

Kjær, Thorvald

1946 De store Vingefang. Iagttagelser over danske Storfugle. København: Det Danske Forlag.

Kjærbølling, Niels

1852 Danmarks Fugle. København: Eget Forlag.

Madsen, Stig Toft,

n.d. The Anthropology of Field Ornithology. Upublicerede noter.

McCracken, Grant

1990 Culture and Consumption: New Approaches to the Symbolic Character of Consumer Goods and Activities. Bloomington: Indiana University Press.

Malinowski, Bronislaw

1922 Argonauts of the Western Pacific. London: Routledge \& Kegan Paul.

Miller, Daniel

1987 Material Culture and Mass Consumption. Oxford: Basil Blackwell.

Olsen, Klaus Malling

1992 En Drift... DOF-Nyt (2):iv-v.

Preuss, Niels Otto

1981 A.H. Faber, en ,gammel“" Fritidsornitolog. Fugle 1(4):26.

Rodahl, Kurt \& Jan Speiermann

1993 Med „Munken“ på Farten - Portræt af en landskendt Ornitolog. Pica 5(1):6-13.

Sahlins, Marshall D.

1963 Poor Man, Rich Man, Big Man, Chief. Comparative Studies in Society and History 5:285303.

Seligman, Charles G.

1910 The Melanesians of British New Guinea. Cambridge: Cambridge University Press.

Skriver, Jan Nør,

$1984 \quad$ Arktisk Gæst i Hanstholm. Fugle 4(1):8.

Sonsino, Steven

1989 Bluff Your Way at Birdwatching. Horsham: Ravette Books.

Speiermann, Jan \& Steen Søgård

$1995 \quad$ Krabben fra Gurre - et Portræt af Erling Krabbe. Pica 6(2):4-10.

Stewart, Susan

1984 On Longing: Narratives of the Miniature, the Gigantic, the Souvenir, the Collection.

Baltimore: The John Hopkins University Press.

Veblen, Thorstein

1975[1899] The Theory of the Leisure Class. New York: Kelley.

Weiner, Annette B.

1988 The Trobrianders of Papua New Guinea. New York: Holt, Rinehart \& Winston.

Wilden, Anthony

1980 System and Structure: Essays in Communication and Exchange. London: Tavistock. 
